\title{
Sid New Disease Reports \\ First report of leaf blight on white spider lily caused by Neoscytalidium dimidiatum in Malaysia
}

M.A. Nurul Nadiah, N.M.I. Mohamed Nor, Z. Latiffah and M. Masratul Hawa*

School of Biological Sciences, Universiti Sains Malaysia, 11800 USM Penang, Malaysia

*E-mail: masratulhawa@usm.my

Received: 23 Mar 2017. Published: 12 Apr 2017. Keywords: foliar fungal plant disease, Hymenocallis littoralis

White spider lily (Hymenocallis littoralis), locally known as Melong Kecil, is a herbaceous and bulbous perennial plant, commonly planted in Malaysia due to its medicinal and ornamental properties. Symptoms of leaf blight on H. littoralis were noticed in early September 2015 in Permatang Pauh, Penang with an incidence of up to $35 \%$. The symptoms appeared as irregular reddish-brown lesion with black pycnidia scattered on the leaf (Fig. 1). When aged, the lesion enlarged and became darker.

Small pieces of the infected leaves were surface sterilised, plated on potato dextrose agar (PDA) and incubated at $25 \pm 1{ }^{\circ} \mathrm{C}$ for three days. A pure culture was obtained by single spore isolation. The fungus obtained was initially white with dense and hairy aerial mycelium and gradually turned dark grey to olive green (Fig. 2). Conidia formed in arthric chains, dark brown, ovoid to ellipsoid, round to rod-shaped with 0- to 1-septate conidia (Fig. 3). Abundant black pycnidia formed on carnation leaf agar with aseptate cylindrical conidia produced by conidiogenous cells. The fungus was identified as Neoscytalidium dimidiatum based on the description of its pycnidial and mycelial anamorphs (Crous et al., 2006). The identity of the isolated fungus was confirmed by PCR amplification of the internal transcribed spacer (ITS) region using the ITS1/ITS4 primers (White et al., 1990). Based on a BLAST search, the isolate showed $99 \%$ identity with an isolate of $N$. dimidiatum (GenBank Accession No. KP132486). DNA sequences were deposited in GenBank (KX290313).

A pathogenicity test was done using the mycelial plug method. A healthy leaf of $H$. littoralis was surface sterilised with $70 \%$ ethanol prior to inoculation and four inoculation points were made using a sterile cork borer $(6 \mathrm{~mm})$. Fungal mycelial plugs were obtained from a seven-day-old PDA culture and transferred onto three inoculation points, whilst a PDA plug without mycelium was placed on the fourth inoculation point as a control The test was repeated twice. The inoculated leaves were placed in surfacesterilised trays and incubated at $25 \pm 1^{\circ} \mathrm{C}$ with a relative humidity of $85 \%$. Dark brown-reddish lesions appeared five days after inoculation (Fig. 4) As the disease progressed, the presence of black pycnidia was noticed on the lesion surface and the leaves began yellowing ten days after inoculation (Fig. 5). The symptoms produced were similar to those observed in the fields and the control remained symptomless. Neoscytalidium dimidiatum isolates were consistently recovered from symptomatic leaves of $H$.

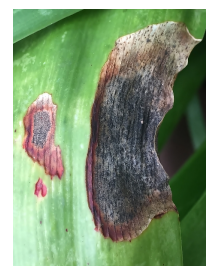

Figure 1

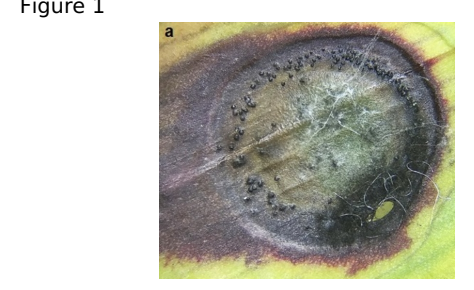

Figure 4 littoralis thus fulfilling Koch's postulates.

This is the first report of $N$. dimidiatum causing leaf blight on white spider lily (H. littoralis). Previous studies showed $N$. dimidiatum was responsible for shoot blight, canker and gummosis on Citrus sinensis (Polizzi et al., 2009); collar and root rot of Jatropha curcas (Marchado et al., 2012); and stem canker on Hylocereus polyrhizus (Masratul Hawa et al., 2013). Information on the aetiology of white spider lily leaf blight can improve management practices to prevent serious yield losses.

\section{Acknowledgements}

This work was supported by Short Term Grant (304/PBIOLOGI/6313226) from Universiti Sains Malaysia.

\section{References}

Crous PW, Slippers B, Wingfield MJ, Rheeder J, Marasas WFO, Philips AJL, Alves A, Burgess T, Barber P, Groenewald JZ, 2006. Phylogenetic lineages in the Botryosphaeriaceae. Studies in Mycology 55, 235-253. http://dx.doi.org/10.3114/sim.55.1.235

Machado AR, Pinho DB, Dutra DC, Pereira OL, 2012. First report of collar and root rot of physic nut (Jatropha curcas) caused by Neoscytalidium dimidiatum in Brazil. Plant Disease 96, 1697.

http://dx.doi.org/10.1094/PDIS-05-12-0504-PDN

Masratul Hawa M, Salleh B, Latiffah Z, 2013. Identification and molecular characterizations of Neoscytalidium dimidiatum causing stem canker of redfleshed dragon fruit (Hylocereus polyrhizus) in Malaysia. Journal of Phytopathology 161, 841-849. http://dx.doi.org/10.1111/jph.12146

Polizzi G, Aiello D, Vitale A, Giuffrida F, Groenewald JZ, Crous PW, 2009. First report of shoot blight, canker, and gummosis caused by Neoscytalidium dimidiatum on citrus in Italy. Plant Disease 93, 1215. http://dx.doi.org/10.1094/PDIS-93-11-1215A

White TJ, Bruns T, Lee S, Taylor JW, 1990. Amplification and direct sequencing of fungal ribosomal RNA genes for phylogenetics. In: Innis MA, Gelfand DH, Sninsky JJ, White TJ, eds. PCR Protocols: A Guide to Methods and Applications, New York, USA: Academic Press, 315-322.

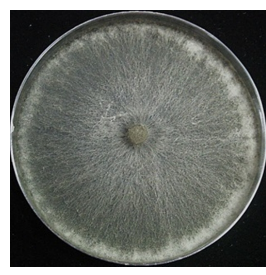

Figure 2

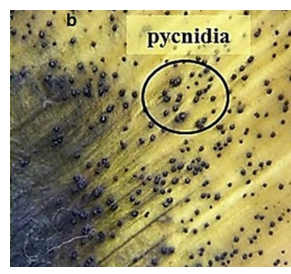

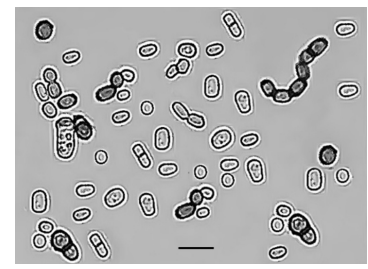

Figure 3

To cite this report: Nurul Nadiah MA, Mohamed Nor NMI, Latiffah Z, Masratul Hawa M, 2017. First report of leaf blight on white spider lily caused by Neoscytalidium dimidiatum in Malaysia. New Disease Reports 35, 16. http://dx.doi.org/10.5197/j.2044-0588.2017.035.016 (c) 2017 The Authors

This report was published on-line at www.ndrs.org.uk where high quality versions of the figures can be found. 